\title{
Application of stabilized hypobromite for controlling membrane fouling and $N$-nitrosodimethylamine formation
}

\author{
Takahiro Fujioka, ${ }^{1, *}$ Hiro Yoshikawa, ${ }^{2}$ Masahiro Eguchi, ${ }^{2}$ \\ Sandrine Boivin, ${ }^{1}$ Hitoshi Kodamatani, ${ }^{3}$
}

${ }^{1}$ Graduate School of Engineering, Nagasaki University, 1-14 Bunkyo-machi, Nagasaki 8528521, Japan

${ }^{2}$ R\&D Center, Organo Corporation, 4-4-1 Nishionuma Minamiku, Sagamihara 252-0332, Japan

${ }^{3}$ Division of Earth and Environmental Science, Graduate School of Science and Engineering, Kagoshima University, 1-21-35 Korimoto, Kagoshima 890-0065, Japan

* Corresponding author: Takahiro Fujioka, Email: tfujioka@nagasaki-u.ac.jp, Ph +81958192695 


\section{Abstract}

2 Chloramination is a conventional and successful pre-disinfection approach to control biological

3 fouling for reverse osmosis (RO) treatment in water reuse. This study aimed to evaluate the

4 possibility of using a new disinfectant—-stabilized hypobromite — in controlling membrane fouling

5 and the formation of a particular carcinogenic disinfection byproduct (DBP) $-N$ -

6 nitrosodimethylamine (NDMA). Our accelerated chemical exposure tests showed that the new

7 disinfectant reduced the permeability of a polyamide RO membrane permeability from 6.7 to 4.1

$8 \mathrm{~L} / \mathrm{m}^{2} \mathrm{hbar}$; however, its treatment impact was equivalent to that of chloramine. The disinfection

9 efficacy of stabilized hypobromite was greater than that of chloramine when evaluated with intact bacterial counts, which suggests its potential for mitigating membrane biofouling. Additional pilot-

11 scale tests using synthetic wastewater demonstrated that pre-disinfection with the use of stabilized 12 hypobromite inhibits membrane fouling. Among 13 halogenated DBPs evaluated, the formation 13 of bromoform by stabilized hypobromite was higher than that by chloramine at a high dose of 10

$14 \mathrm{mg} / \mathrm{L}$, thus suggesting the need for optimizing chemical doses for achieving sufficient biofouling 15 mitigation. NDMA formation upon stabilized hypobromite treatment in two different types of 16 actual treated wastewaters was found to be negligible and considerably lower than that by 17 chloramine treatment. In addition, NDMA formation potential by stabilized hypobromite was $2-5$ 18 orders of magnitude lower than that by chloramine. Our findings suggest the potential of using 19 stabilized hypobromite for controlling NDMA formation and biofouling, which form the keys to 20 successful potable water reuse.

21 Keywords: NDMA; DBPs; biofouling; reverse osmosis; disinfection. 


\section{Introduction}

Potable water reuse has been found to be the most efficient option to augment drinking water supply in regions that experience prolonged droughts (WHO, 2017). Potable water reuse can be achieved by means of purifying secondary wastewater effluents to a level that meets drinking water standards via advanced wastewater treatment processes (AWTPs). AWTPs typically involve microfiltration (MF) or ultrafiltration (UF), reverse osmosis (RO), advanced oxidation process (AOP), and chlorine disinfection (Tang et al., 2018; Warsinger et al., 2018). In particular, RO treatment has been found to be an effective separation technology for eliminating most impurities from wastewater. However, the presence of dissolved nutrients in the pre-treatment process (i.e., MF or UF) can trigger the proliferation of microorganisms and cause biofouling (Leddy et al., 2017).

To alleviate biofouling, a pre-disinfection process via chloramination is performed prior to the RO treatment (Goh et al., 2018). However, this pre-disinfection process also leads to the formation of carcinogenic disinfection byproducts (DBPs) that include $N$-nitrosodimethylamine (NDMA) and $N$-nitrosomorpholine (NMOR) (Mitch et al., 2003b; Farré et al., 2011b; Krasner et al., 2013; Chuang et al., 2019). NDMA is formed via chloramination when there is a reaction between chloramine and secondary, tertiary, or quaternary amines (NDMA precursors). NDMA precursors include dimethylamine (DMA), trimethylamine (TMA), dimethylbenzylamine (DMBA), pharmaceuticals (e.g., ranitidine), and water treatment polymers (Le Roux et al., 2011; Shen and Andrews, 2011; Zhou et al., 2014; West et al., 2016; Sgroi et al., 2018). Because of the NDMA formed after chloramination and the NDMA present in raw wastewater, NDMA concentrations prior to RO treatment can be $>20-100$ ng/L (Sedlak et al., 2005; Fujioka et al., 2012). However, 
RO treatment can only achieve $<50 \%$ NDMA rejection (Bellona et al., 2008; Fujioka et al., 2013b), and thus, ultraviolet (UV) or UV-based AOP treatment becomes the only reliable barrier to attenuate NDMA concentration within the recommended guideline levels (e.g., $10 \mathrm{ng} / \mathrm{L}$ ) (Plumlee et al., 2008; McCurry et al., 2017). Thus, any reduction in NDMA formation prior to the RO process is beneficial for the improved safety of the potable water reuse.

To alleviate NDMA formation, several chloramination-based approaches have been proposed. For instance, chlorination via pre-formed monochloramine or distributed chlorine dosing can significantly reduce NDMA formation (Mitch et al., 2005; Schreiber and Mitch, 2005; Furst et al., 2018). In this context, as an alternative to the conventional chloramination, here, this study proposes a pre-disinfection process using a new disinfectant-stabilized hypobromite. Hypobromite $\left(\mathrm{BrO}^{-}\right)$is an oxidizing reagent that is stronger than chloramine, and it is normally used as a strong disinfectant in industrial water applications (e.g., cooling water) (Cristiani and Perboni, 2014). It is noted that hypobromite can be stably present in water when it is stabilized with sulfamic acid at a high $\mathrm{pH}$. However, the effectiveness of the new disinfectant (i.e., stabilized hypobromite) in mitigating biofouling and NDMA formation remains unclear. Moreover, bromine-based disinfectants can possibly form brominated DBPs, which can be more toxic than chlorinated DBPs (Sharma et al., 2014). Addressing these concerns is critical to adaptation of the new disinfectant to pre-disinfection process in water recycling applications.

Against this backdrop, this study evaluated the potency of stabilized hypobromite treatment in controlling membrane biofouling and NDMA formation during the RO treatment of treated wastewater. The study involved three major evaluations: (a) changes in the RO membrane performance; (b) bactericidal capacity and biofouling control performance; and (c) formation 
potential of NDMA and other DBPs. Through every phase of the study, the results obtained using stabilized hypobromite were compared with those obtained with chloramine.

\section{Materials and methods}

\subsection{Chemicals}

71 Analytical grade chemicals $\left(\mathrm{NaCl}, \mathrm{NaHCO}_{3}, \mathrm{CaCl}_{2}, \mathrm{NH}_{4} \mathrm{Cl}\right.$, and $\mathrm{HCl}$ ) were purchased from Kanto Chemical Co. (Tokyo, Japan). A NaOCl solution, with over $12 \%$ chlorine concentration, was purchased from Tosoh Co. (Tokyo, Japan), and a stock solution of chloramine was prepared at 0.2 $\mathrm{M}$ by mixing $\mathrm{NaOCl}$ and $\mathrm{NH}_{4} \mathrm{Cl}$ solutions. Further, hypobromite stabilized by sulfamic acid was used as stabilized hypobromite in this study. A stock solution of stabilized hypobromite comprised of hypobromite, sulfamic acid and sodium hydroxide was supplied by Organo Co. (Tokyo, Japan). Chemicals selected as NDMA precursors were DMA, TMA, and N,N-dimethylbenzylamine (DMBA) were purchased from Kanto Chemical Co. (Tokyo, Japan) (Table 1). A flat sheet polyamide composite RO membrane sample (namely ESPA2) were supplied by Hydranautics/Nitto (Oceanside, CA, USA). This study used two types of treated wastewater: an

81 ultrafiltration (UF)-treated wastewater and membrane bioreactor (MBR)-treated wastewater, both of which were collected at wastewater treatment plants in Japan. 
Table 1 - Molecular structures of NDMA and selected NDMA precursors.

\begin{tabular}{|c|c|c|c|c|c|}
\hline \multirow{2}{*}{$\begin{array}{l}\text { Classification } \\
\text { Name }\end{array}$} & \multicolumn{2}{|c|}{$N$-nitrosamines } & \multicolumn{3}{|c|}{ NDMA precursors } \\
\hline & NDMA & NMOR & DMA & TMA & DMBA \\
\hline \multicolumn{6}{|l|}{ Structure } \\
\hline Molecular weight $[\mathrm{g} / \mathrm{mol}]$ & 74.1 & 116.1 & 45.1 & 59.1 & 135.1 \\
\hline $\mathrm{pKa}^{*}[-]$ & 3.6 & 3.2 & 10.7 & 9.7 & 9.1 \\
\hline Charged spices at $\mathrm{pH} 6^{*}[\%]$ & 0 & 0 & $100(+)$ & $100(+)$ & 0 \\
\hline Charged spices at $\mathrm{pH} 8^{*}[\%]$ & 0 & 0 & $99(+)$ & $98(+)$ & $8(+)$ \\
\hline
\end{tabular}

*Calculated using MarvinSketch software (ChemAxon, Budapest, Hungary).

\subsection{Test protocols}

\subsubsection{Membrane degradation tests}

The deformation of RO membranes using a disinfectant agent was simulated through immersing polyamide membrane samples in a $500 \mathrm{~mL}$ solution dosed with a disinfectant (chloramine, stabilized hypobromite, or $\mathrm{NaOCl}$ ) or a solution without chemical addition (Control). Each chemical reagent was dosed at a concentration of $300 \mathrm{mg}-\mathrm{Cl}_{2} / \mathrm{L}$ in a synthetic wastewater $(20 \mathrm{mM}$ $\mathrm{NaCl}, 1 \mathrm{mM} \mathrm{CaCl}_{2}, 1 \mathrm{mM} \mathrm{NaHCO}, 1 \mathrm{mg}-\mathrm{Al} / \mathrm{L}$ ) or dosed to achieve a concentration of $>200 \mathrm{mg}-$ $\mathrm{Cl}_{2} / \mathrm{L}$ in the UF-treated wastewater. It is noted that the aluminum ions were added in the synthetic wastewater to enhance oxidative degradation reactions through catalytic effects (Cran et al., 2011). The solution $\mathrm{pH}$ was adjusted at 7.0, and the samples were left to stand in the dark at $25{ }^{\circ} \mathrm{C}$ for $100 \mathrm{~h}$, which is equivalent to the cumulative exposure during one year operation with a standard chloramine residual concentration at the membrane surface (e.g., $3 \mathrm{mg}-\mathrm{Cl}_{2} / \mathrm{L}$ ). Thereafter, the pure water permeability and conductivity rejection performance of each membrane sample was determined using the bench-scale RO system (Figure S1). Conductivity rejection was determined at a permeate flux of $43 \mathrm{~L} / \mathrm{m}^{2} \mathrm{~h}$. The permeate flux in this study was as twice as high as the typical 
value of full-scale RO processes (i.e., approximately $20 \mathrm{~L} / \mathrm{m}^{2} \mathrm{~h}$ ). However, because variation in

101 conductivity rejection between 43 and $20 \mathrm{~L} / \mathrm{m}^{2} \mathrm{~h}$ is negligible (Fujioka et al., 2013a), the conductivity rejection data in this study can be considered valid.

\subsubsection{Disinfection for bactericidal effects}

104 The disinfection efficacy of stabilized hypobromite and chloramine was evaluated by determining the number of viable bacteria (denoted as "intact bacteria" in this study) in treated wastewater using epifluorescence microscopy (Section 2.3.1). A similar approach for evaluating the disinfection efficacy using intact bacterial counts has been found elsewhere (Park et al., 2016; Farhat et al., 2018). In this study, wach disinfection test was conducted using $200 \mathrm{~mL}$ of treated wastewater. A disinfectant (stabilized hypobromite and chloramine) was added into the sample at a dose of $10 \mathrm{mg}-\mathrm{Cl}_{2} / \mathrm{L}$. It is noted that stabilized hypobromite dose is presented in $\mathrm{mg}-\mathrm{Cl}_{2} / \mathrm{L}$ by

111 converting the concentration of bromine in terms of chlorine. Thereafter, the flasks were placed in

112 a temperature-controlled room $\left(25^{\circ} \mathrm{C}\right)$ for 1 or $5 \mathrm{~h}$. The reaction time was determined based on a

113 contact time of chloramination prior to RO process at full-scale water recycling systems, in which

114 the contact time can vary considerably from 1 to 24 h (Farré et al., 2011a). Following the sample 115 collection, residual chemical was quenched by adding a sodium sulfite solution.

\subsubsection{Membrane fouling mitigation}

117 The effect of stabilized hypobromite in controlling membrane fouling was evaluated using a pilot-

118 scale RO system holding one 4-in ESPA2 RO membrane element, with a surface area of $7.9 \mathrm{~m}^{2}$ 119 and a nominal salt rejection of $99.6 \%$ (Figure S2). Groundwater (Table S1) was continuously fed 120 to the pilot-scale system as an artificial RO feedwater after being dosed with acetic acid as carbon 121 nutrients at $5 \mathrm{mg} / \mathrm{L}$. In addition, stabilized hypobromite was added to the RO feed reservoir at 1.0 
$\mathrm{mg}-\mathrm{Cl}_{2} / \mathrm{L}$ for $3 \mathrm{~h}$ a day. The RO system was operated at a constant flux of $17-20 \mathrm{~L} / \mathrm{m}^{2} \mathrm{~h}$ and a water recovery rate of $25-30 \%$. The level of membrane fouling was evaluated based on the increases in pressure drop $(\Delta P)$ and transmembrane pressure (TMP) as follows:

$$
\Delta P=P_{f}-P_{c}
$$

where $P_{f}=$ feed pressure $(\mathrm{kPa}), P_{c}=$ concentrate pressure $(\mathrm{kPa})$, and $P_{p}=$ permeate pressure $(\mathrm{kPa})$.

\subsubsection{DBP formation tests}

129 The formation of halogenated DBPs was evaluated using the UF-treated wastewater. Each

130 formation test was conducted using $1,000 \mathrm{~mL}$ of treated wastewater in a sealable perfluoroalkoxy

131 alkane (PFA) flask. A disinfectant (stabilized hypobromite and chloramine) was added into the

132 sample at a dose of $10 \mathrm{mg}-\mathrm{Cl}_{2} / \mathrm{L}$. Prior to the disinfectant addition, each sample solution's $\mathrm{pH}$ was 133 adjusted by adding an $\mathrm{HCl}$ solution so that the sample solution $\mathrm{pH}$ becomes 7.0 after the

134 disinfectant addition. The flasks were then placed in a temperature-controlled room $\left(25^{\circ} \mathrm{C}\right)$ for 5

$135 \mathrm{~h}$ to advance the reactions. Following the sample collection, residual chemical was quenched by 136 adding a sodium sulfite solution.

137 The formation of NDMA and NMOR was evaluated using the UF-treated and MBR-treated 138 wastewaters. Each formation test was conducted using $1,000 \mathrm{~mL}$ of treated wastewater in a 139 sealable PFA flask. A disinfectant (stabilized hypobromite and chloramine) was added into the 140 sample at a dose of $3,5,10$, or $100 \mathrm{mg}-\mathrm{Cl}_{2} / \mathrm{L}$. Prior to the disinfectant addition, each sample

141 solution's $\mathrm{pH}$ was adjusted by adding an $\mathrm{HCl}$ solution so that the sample solution $\mathrm{pH}$ becomes 7.0 
after the disinfectant addition. The flasks were left in a temperature-controlled room $\left(25^{\circ} \mathrm{C}\right)$ for 5 or $48 \mathrm{~h}$. Thereafter, residual chemical was quenched by adding a sodium sulfite solution.

144 Formation potential of NDMA by stabilized hypobromite and chloramine was evaluated using an artificial wastewater containing one of the selected NDMA precursors. The solutions of each selected precursor (DMA, TMA, or DMBA) were conditioned at $0.1 \mathrm{mg} / \mathrm{L}$ in ultrapure water containing $10 \mathrm{mM}$ of $\mathrm{NaHCO}_{3}$. Each formation test was conducted using $100 \mathrm{~mL}$ of artificial wastewater in a sealable PFA flask. Prior to the disinfectant addition, the solution $\mathrm{pH}$ of each sample was adjusted by adding an $\mathrm{HCl}$ solution so that the sample solution $\mathrm{pH}$ becomes 6.0 or 8.0 after the disinfectant addition. The solution $\mathrm{pHs}$ were determined based on $\mathrm{RO}$ feed $\mathrm{pH}$ of typical full-scale plants, which typically varies from 6 to 8 across the entry of the first stage to the exit of the third stage (Fujioka et al., 2013b). Thereafter, a disinfectant (stabilized hypobromite and chloramine) was added into the sample at a dose of $100 \mathrm{mg}-\mathrm{Cl}_{2} / \mathrm{L}$, which was determined based on a previous study (Selbes et al., 2018). The flasks were then placed in a temperature-controlled room $\left(25^{\circ} \mathrm{C}\right)$ for $0,2,5,24$ or $120 \mathrm{~h}$, and residual chemical was quenched by adding a sodium sulfite solution.

\subsection{Analytical techniques}

\subsubsection{Bacterial analysis}

159 Intact bacterial counts in the UF-treated wastewater before and after disinfection were determined

160 using an epifluorescence microscope BZ-X800 (Keyence Co., Osaka, Japan). Prior to the analysis, 161 each sample $(0.2 \mu \mathrm{L})$ was filtered using a track-etched polycarbonate membrane filter with a pore 162 size of $0.22 \mu \mathrm{m}$ and a diameter of $13 \mathrm{~mm}$ (Meric, Tokyo, Japan). The membranes were stained 163 with a LIVE/DEAD BacLight Bacterial Viability Kit (Thermo Fisher Scientific K.K., Tokyo, 
Japan) (Boulos et al., 1999). After 15 min incubation period, bacterial number deposited on approximately $3 \%$ of the filter surface area was counted as damaged bacteria (red color) and total bacteria (green color). Intact bacterial counts were determined by deducting the number of damaged bacteria stained with propidium iodide (PI) from the number of total bacteria (stained with SYTO 9).

\subsubsection{Chemical analysis}

170 Concentrations of stabilized hypobromite and chloramine were measured using a colorimeter (DR-

171 3900, Hach Co., Loveland, CO, USA). Concentrations of trihalomethanes, haloacetic acids and

172 bromo chloroacetonitrile were determined using gas chromatography mass spectrometry (MS)

173 (Xie, 2001; Nikolaou et al., 2002). Concentrations of chloric acid and bromate were determined

174 using an ion chromatography (Johns et al., 2008) and liquid chromatography-MS/MS (Snyder et

175 al., 2005), respectively. Concentrations of NDMA and NMOR were analyzed using a high176 performance liquid chromatography-inline anion exchange reaction-photochemical reaction177 chemiluminescence (HPLC-AEM-PR-CL) (Kodamatani et al., 2009; Kodamatani et al., 2018).

178 Results from the analytical method signified that the detection limit of NDMA and NMOR was $179 \quad 0.4$ and $1.4 \mathrm{ng} / \mathrm{L}$, respectively.

\section{Results and discussion}

\subsection{Membrane properties}

182 The impact of chemical exposure on the salt separation performance and permeability of

183 polyamide RO membranes was evaluated through accelerated tests, in which RO membrane

184 samples were immersed in artificial wastewater with high concentrations of chemical agents 
185 (stabilized hypobromite, chloramine, chlorine, or Control). Figure 1 illustrates the permeability 186 and conductivity rejection after $100 \mathrm{~h}$ of exposure to chlorine, chloramine, or stabilized 187 hypobromite in a pure water matrix and UF-treated wastewater. As predicted, chlorine exposure 188 resulted in considerably high pure water permeability $\left(11.2 \mathrm{~L} / \mathrm{m}^{2} \mathrm{hbar}\right)$ and a very low conductivity 189 rejection (91.2\%) relative to Control (permeability of $7.6 \mathrm{~L} / \mathrm{m}^{2} \mathrm{hbar}$ and conductivity rejection of 190 99.1\%) (Figure 1a). This deterioration is very likely caused by the destruction of the polyamide 191 skin layer, which can be induced by hydrolysis and degradation of the cross-linked polyamide 192 network (Ohno et al., 2016; Gohil and Suresh, 2017). Relative to chlorine, the impact of the 193 conventional disinfectant (chloramine) on membrane transport was significantly low; the pure 194 water permeability and conductivity rejection after chloramine (permeability of $7.2 \mathrm{~L} / \mathrm{m}^{2} \mathrm{hbar}$ and 195 conductivity rejection of $98.5 \%$ ) were comparable with the corresponding ones of the Control 196 (permeability of $7.6 \mathrm{~L} / \mathrm{m}^{2}$ hbar and conductivity rejection of $99.1 \%$ ). Further, the results show that 197 the impact of exposing the membrane to stabilized hypobromite was insignificant. 

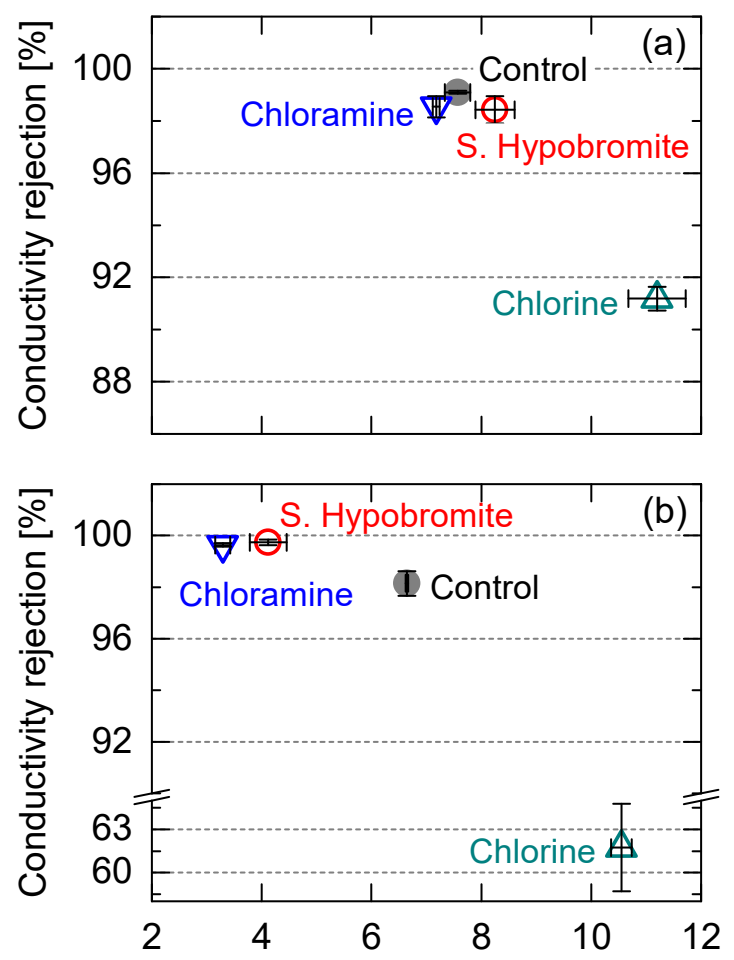

Pure water permeability $\left[\mathrm{L} / \mathrm{m}^{2} \mathrm{hbar}\right]$

199 Figure 1 - Permeability and conductivity rejection after $100 \mathrm{~h}$ of exposure to chlorine, chloramine,

200 or stabilized (S.) hypobromite in (a) pure water matrix and (b) ultrafiltration (UF)-treated wastewater. Symbols and error bars represent the average and range, respectively, of duplicated chemical exposure tests.

203 The impact of chemical exposure was more pronounced when simulated in actual UF-treated wastewater (Figure 1b). It is noted that during the chemical exposure tests with chloramine, chloramine concentrations reduced progressively according to reaction time. Thus, the chloramine stock solutions were dosed every $24 \mathrm{~h}$ to recover their chloramine concentrations above $200 \mathrm{mg} / \mathrm{L}$

(Figure S3). Similar to the case of the artificial wastewater, chlorine exposure was found to 208 increase pure water permeability to $10.5 \mathrm{~L} / \mathrm{m}^{2} \mathrm{hbar}$ and result in a considerably low conductivity 209 rejection (61.7\%). In contrast, both stabilized hypobromite and chloramine treatment resulted in a 210 considerable reduction in water permeability to 4.1 and $3.3 \mathrm{~L} / \mathrm{m}^{2} \mathrm{hbar}$ from $6.7 \mathrm{~L} / \mathrm{m}^{2} \mathrm{hbar}$ (Control), 211 respectively. Accordingly, the separation performance (i.e., conductivity rejection) remarkably 
increased to $99.6 \%$ (chloramine) and $99.7 \%$ (stabilized hypobromite) from 98\% (Control). The

213 improved separation performance and reduced water permeability in the treated wastewater

214 indicate that stabilized hypobromite and chloramine treatment may not have caused oxidative

215 damages to the RO membranes that can deteriorate both separation performance and water

216 permeability (da Silva et al., 2006). Instead, stabilized hypobromite and chloramine treatment may

217 have caused structural changes in the RO membrane matrix, because different types of RO

218 membranes typically exhibit a tradeoff between their water permeability and separation

219 performance (e.g., improved separation performance is achieved at the cost of decreased water

220 permeability) (Fujioka et al., 2015). Although accelerated tests have limitations in simulating long-

221 term exposure of chemicals to RO membranes due to differences in the degradation mechanisms

222 (Stolov and Freger, 2019), the simulated test results suggest that stabilized hypobromite and

223 chloramine offer comparable efficacies in terms of the level of changes in the RO membrane

224 properties during pre-disinfection.

\subsection{Disinfection}

\subsubsection{Bactericidal effects}

227 The disinfection efficacy of stabilized hypobromite and chloramine was evaluated based on intact

228 bacterial counts via epifluorescence microscopy (Figure 2). Conventional heterotrophic plate 229 count (HPC) method, which only provides the number of colony-forming bacteria that use organic 230 carbon, is commonly used for evaluating and ensuring microbiological water quality in treated 231 water. As compared with HPC, the methods based on fluorescence microscopy coupled with 232 nucleic acid stains cover almost all bacterial cells in water with the information of their state (intact 233 or damaged). In general, stabilized hypobromite is superior to chloramine in terms of reduction in 
bacteria. Chloramination resulted in the reduction of intact bacterial counts from $8.1 \times 10^{5}$ counts $/ \mathrm{mL}$ to $3.2 \times 10^{5}(1 \mathrm{~h})$ and $2.3 \times 10^{5}(5 \mathrm{~h})$ counts $/ \mathrm{mL}$. Stabilized hypobromite showed a greater reduction in intact bacterial counts from $8.1 \times 10^{5}$ counts $/ \mathrm{mL}$ to $1.7 \times 10^{5}(1 \mathrm{~h})$ and $1.3 \times$ $10^{5}(5 \mathrm{~h})$ counts $/ \mathrm{mL}$. Considering that biofouling layers on RO membranes can be composed of various types of bacteria in treated wastewater, intact bacterial counts can be one of the indicators stabilized hypobromite is more likely to mitigate biofouling than chloramine.

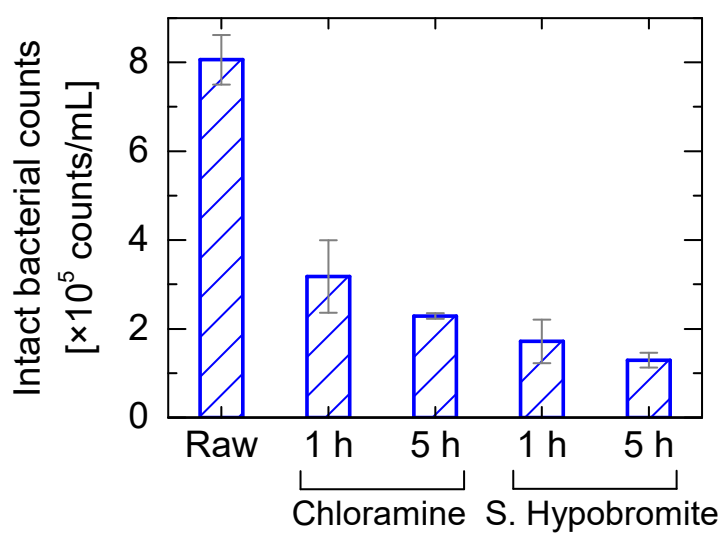

242 Figure 2 - Effects of disinfection using chloramine and stabilized hypobromite in ultrafiltrationtreated wastewater: intact bacterial counts determined by epifluorescence microscopy. Error bars indicate the standard deviations for duplicated disinfection tests.

\subsubsection{Fouling mitigation}

246 The degree of membrane fouling mitigation with the use of stabilized hypobromite was next 247 evaluated at the pilot scale by comparison with that without disinfection addition (Control). Due 248 to the limitations of the facility available for this pilot-scale test, this study used filtered 249 groundwater dosed with acetic acid as synthetic wastewater in this study. Stabilized hypobromite 250 treatment was conducted by intermittently applying stabilized hypobromite pre-disinfection at a 251 dose of $1.0 \mathrm{mg}-\mathrm{Cl}_{2} / \mathrm{L}$ for $3 \mathrm{~h} / \mathrm{d}$; Figure 3 shows the corresponding results. Over the course of the 
17-day test, the pressure drop $(\Delta P)$ across the feed stream of the Control system was observed to increase remarkably from 6 to $20 \mathrm{kPa}$ (Figure 3a), thereby indicating clogging in the RO feed channel. Here, it is noted that full-scale clogging can cause a reduction in the RO feed pressure in the inlet of the subsequent RO elements. In contrast to the Control system, the pressure drop in the stabilized hypobromite system remained almost constant (at 7-8 $\mathrm{kPa}$ ). This result indicates that stabilized hypobromite effectively suppresses bacterial growth (clogging) in the RO feed channel. Next, from Figure 3b, the transmembrane pressure (TMP) in the Control system progressively increased from 490 to $590 \mathrm{kPa}$ during the tests. This increase in TMP indicates increased hydraulic resistance across the $\mathrm{RO}$ membrane, which means that a higher energy is required to maintain a specific permeate flux. In contrast, the stabilized hypobromite system achieved a stable TMP in the range of 440-500 MPa. It is noted that another membrane fouling test using chloramine predisinfection at a dose of $3.0 \mathrm{mg}-\mathrm{Cl}_{2} / \mathrm{L}$ resulted in a constant decrease in transmembrane pressure 264 (TMP) and conductivity rejection during over a period of only 18 days (Figure S4). The decreased TMP (i.e., increased water permeability) and decreased separation performance indicate that chloramination in the synthetic wastewater may have induced deterioration of the RO membrane.

267 Despite the differences in the membrane fouling levels between the two RO systems (i.e., Control and stabilized hypobromite), the ion separation performances of both systems were comparable (Figure 3c). These results indicate that intermittent pre-disinfection with stabilized hypobromite can mitigate membrane fouling. Further investigations focusing on the mechanisms associated 271 with membrane fouling mitigation with the use of stabilized hypobromite are necessary to ensure 272 that the versatility of stabilized hypobromite in water recycling applications is taken into 273 consideration, particularly because actual wastewaters contain diverse ranges of foulants and their 274 concentrations vary considerably depending on seasons and locations. 

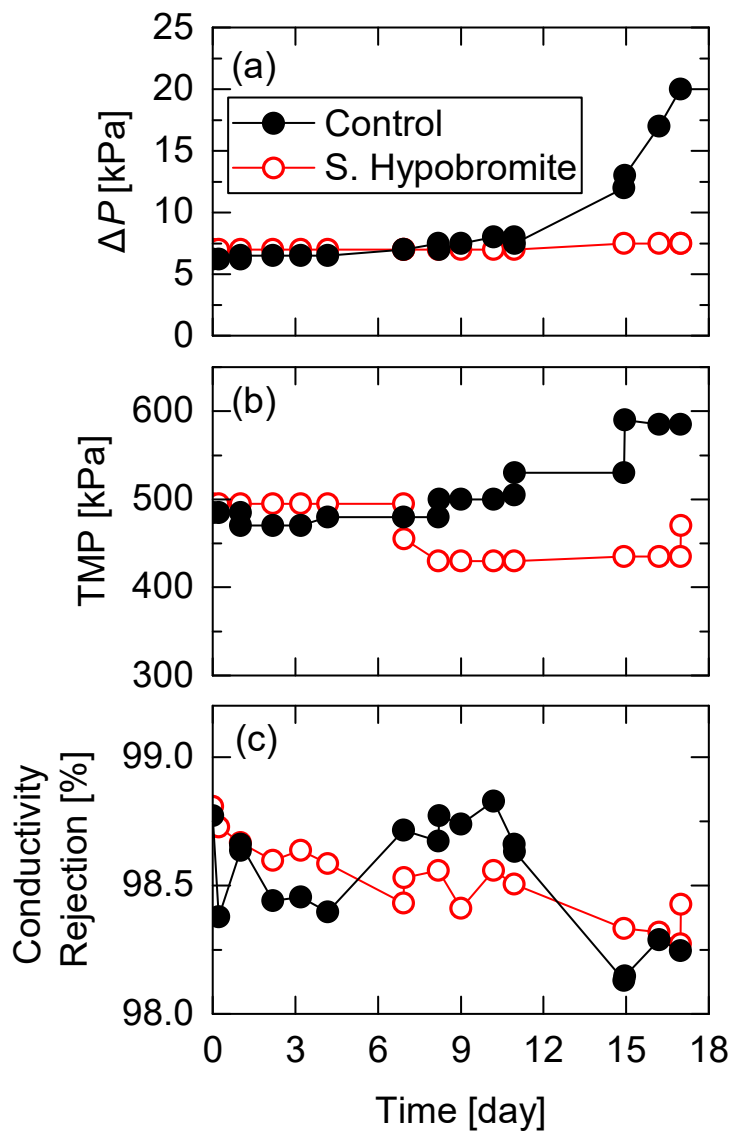

276 Figure 3 - Change in (a) pressure drop $(\Delta P)$ across feed channel, (b) transmembrane pressure (TMP) across reverse osmosis (RO) membrane, and (c) conductivity rejection during RO treatment of synthetic wastewater (Permeate flux of $19-20 \mathrm{~L} / \mathrm{m}^{2} \mathrm{~h}$, permeate recovery of $25-30 \%$, and feed temperature of $14-17^{\circ} \mathrm{C}$ ). Throughout the tests, no hypobromite was detected in the RO permeate.

\subsection{DBP formation}

\subsubsection{Halogenated DBPs}

282 The formation of 13 halogenated DBPs was evaluated at a chloramine or stabilized hypobromite

283 dose of $10 \mathrm{mg}-\mathrm{Cl}_{2} / \mathrm{L}$ and a reaction period of $5 \mathrm{~h}$; the results are listed in Table 2. In general, the 284 formation potentials of DBPs by chloramine and stabilized hypobromite appeared comparable.

285 Here, it is important to note that the formation of bromate $\left(\mathrm{BrO}_{3}\right)$, a carcinogenic $\mathrm{DBP}$, via stabilized hypobromite treatment was found to be negligible at $1 \mu \mathrm{g} / \mathrm{L}$, which is below the WHO 
guideline value for drinking water $(10 \mu \mathrm{g} / \mathrm{L})$ (WHO, 2011). Stabilized hypobromite is an intermediate form of transformation from bromine to bromate, and bromate formation can only be achieved by strong oxidants such as ozone and hypochlorite (Fang et al., 2017; Yang et al., 2017).

290 Therefore, stabilized hypobromite cannot transform to bromate in the absence of these strong 291 oxidants. Among the four trihalomethanes (THMs) - chloroform, bromodichloromethane, 292 dibromochloromethane, and bromoform - the concentration of bromoform after stabilized 293 hypobromite treatment $(90 \mu \mathrm{g} / \mathrm{L})$ was greater than that after chloramine treatment $(24 \mu \mathrm{g} / \mathrm{L})$. The 294 high bromoform concentration of the treated wastewater resulted in its THM concentration being 295 greater than the maximum contaminant level (MCL) of THMs, which has been established for 296 drinking water in CA, USA. However, trihalomethanes, including bromoform, are typically 297 rejected by 40-50\% (Doederer et al., 2014); thus, THM concentration in the RO permeate will be 298 substantially lower than that in the RO feed. It is to be noted that the formation potential of THMs can vary considerably depending on the source of treated wastewater and disinfection conditions 300 (e.g., reaction time and chemical dose). To identify whether the formation of halogenated DBPs 301 by stabilized hypobromite is acceptable, evaluations of various wastewaters used for potable reuse 302 and the optimization of operating conditions are necessary in future. 
Table 2 - Disinfection byproduct (DBP) concentrations after chloramine or stabilized hypobromite treatment of ultrafiltration-treated wastewater (chemical dose of $10 \mathrm{mg}-\mathrm{Cl}_{2} / \mathrm{L}$, reaction time of $5 \mathrm{~h}$, temperature of $25^{\circ} \mathrm{C}$, and initial $\mathrm{pH}$ of 7.0). The residual concentrations of chloramine and stabilized hypobromite after the reaction were 5.5 and $2.4 \mathrm{mg}-\mathrm{Cl}_{2} / \mathrm{L}$, respectively.

\begin{tabular}{llllll}
\hline DBP & Unit & $\begin{array}{l}\text { MCL in } \\
\text { CA, USA }\end{array}$ & $\begin{array}{l}\text { Before pre- } \\
\text { disinfection }\end{array}$ & $\begin{array}{l}\text { Chloramine } \\
\text { Stabilized } \\
\text { hypobromite }\end{array}$ \\
\hline Trihalomethane & $\mu \mathrm{g} / \mathrm{L}$ & 80 & $<8$ & 36 & 100 \\
-Chloroform & $\mu \mathrm{g} / \mathrm{L}$ & - & $<2$ & $<2$ & $<2$ \\
-Dibromochloromethane & $\mu \mathrm{g} / \mathrm{L}$ & - & $<2$ & 9 & 6 \\
-Bromodichloromethane & $\mu \mathrm{g} / \mathrm{L}$ & - & $<2$ & 3 & $<2$ \\
-Bromoform & $\mu \mathrm{g} / \mathrm{L}$ & - & $<2$ & 24 & 90 \\
Chloroacetic acid & $\mu \mathrm{g} / \mathrm{L}$ & 60 & $<2$ & $<2$ & $<2$ \\
Dichloroacetic acid & $\mu \mathrm{g} / \mathrm{L}$ & - & $<2$ & 2 & $<2$ \\
Trichloroacetic acid & $\mu \mathrm{g} / \mathrm{L}$ & - & 6 & 6 & 6 \\
Bromoacetate & $\mu \mathrm{g} / \mathrm{L}$ & - & $<2$ & n.a. & 2 \\
Dibromoacetic acid & $\mu \mathrm{g} / \mathrm{L}$ & - & $<2$ & n.a. & 19 \\
Bromochloroacetonitrile & $\mu \mathrm{g} / \mathrm{L}$ & - & $<1$ & n.a. & $<1$ \\
Chloric acid & $\mu \mathrm{g} / \mathrm{L}$ & 1,000 & $<3,000$ & $<3,000$ & $<3,000$ \\
Bromate & $\mu \mathrm{g} / \mathrm{L}$ & 10 & $<1$ & n.a. & 1 \\
\hline
\end{tabular}

*-: Not established, n.a.: Not analyzed.

\subsection{2 $N$-nitrosamines}

The potential of DBP formation upon the chloramine and stabilized hypobromite treatment of two different treated wastewaters was evaluated at a chemical dose of $3-10 \mathrm{mg}-\mathrm{Cl}_{2} / \mathrm{L}$ and a reaction time of $5 \mathrm{~h}$. Chloramine treatment of the UF-treated wastewater resulted in a considerable increase in NDMA concentration from 4 to $21 \mathrm{ng} / \mathrm{L}$ (Figure 4a). In contrast, the NMOR concentration after the chloramine treatment was low at $<3 \mathrm{ng} / \mathrm{L}$ (Figure 4b). It is noted that the health-based guideline value of NMOR has been set at as low as $1 \mathrm{ng} / \mathrm{L}$ for recycled water intended for potable water reuse in Australia (NRMMC et al., 2008). However, NMOR is strongly rejected by RO (typically $>90 \%$ ); thus, NMOR concentrations greater than the regulatory value in the specific treated wastewater are less likely to form an issue. A similar increasing trend for the formation of NDMA and NMOR by chloramine was observed for the MBR-treated wastewater, whereas 
NDMA formed by stabilized hypobromite reached only up to $3 \mathrm{ng} / \mathrm{L}$. It is important to note that 321 the residual chloramine concentration in the full-scale RO process in water recycling is usually maintained at $>2-3 \mathrm{mg}-\mathrm{Cl}_{2} / \mathrm{L}$; thus, it is safe to say that a residual chloramine concentration of 3.7 $\mathrm{mg}-\mathrm{Cl}_{2} / \mathrm{L}$ under the $10 \mathrm{mg}-\mathrm{Cl}_{2} / \mathrm{L}$ dose condition in UF-treated wastewater simulated the actual 324 chloramination (Figure 4c). The formation of NDMA by chloramine possibly occurred through a reaction between monochloramine and NDMA precursors in the treated wastewater because chloramine species at the test solution $\mathrm{pH}$ of 7 include monochloramine and a small fraction of

327 dichloramine (Kinani et al., 2012). Throughout the tests, the oxygen concentration and solution $328 \mathrm{pH}$, which can influence NDMA formation by chloramine (Le Roux et al., 2012; Spahr et al., 329 2017), remained almost stable (Figure S5). This implies that any further extension of the 330 chloramine reaction time can lead to the formation of greater amounts of NDMA, as previously 331 reported in literature (Farré et al., 2011a). In contrast to chloramine, stabilized hypobromite 332 showed a negligible increase in NDMA and NMOR for both treated wastewaters (Figures 4a and 333 4b). This result indicates that the yield of NDMA by stabilized hypobromite was significantly 334 lower than the one by chloramine. 

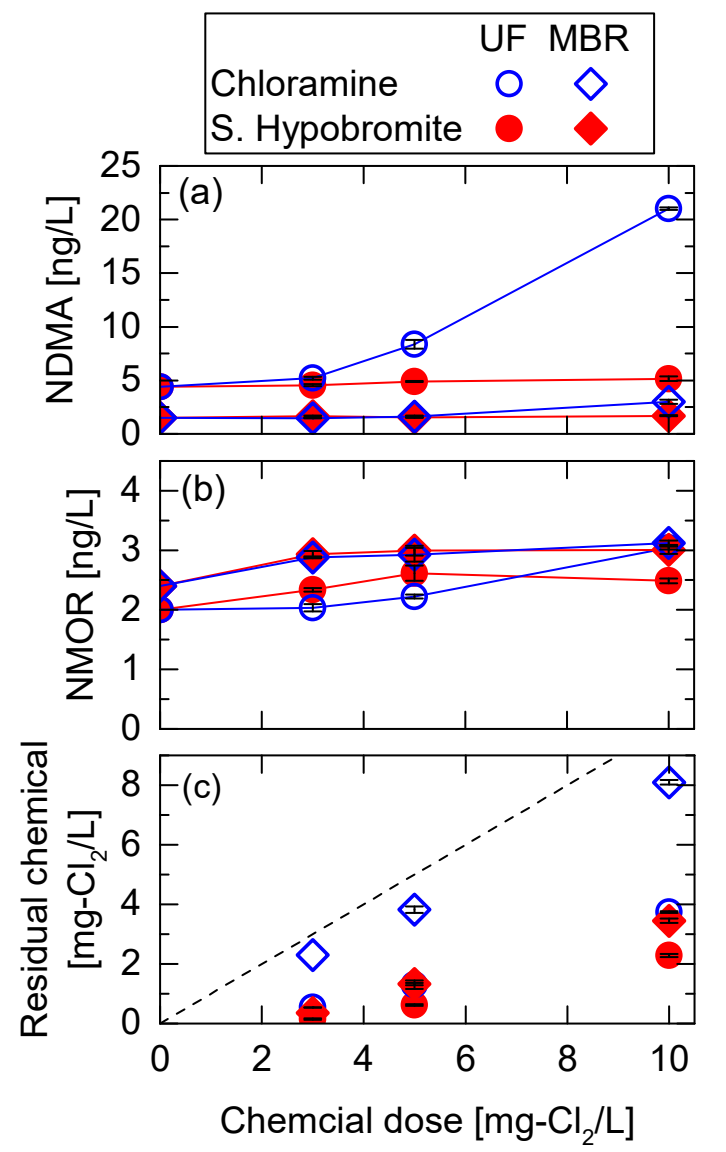

336 Figure 4 - (a) $N$-nitrosodimethylamine (NDMA) and (b) $N$-nitrosomorpholine (NMOR) 337 concentrations in ultrafiltration (UF)-treated or membrane bioreactor (MBR)-treated wastewaters as functions of chloramine and stabilized hypobromite doses, and (c) residual chemical concentrations after each test (reaction time of $5 \mathrm{~h}$, temperature of $25^{\circ} \mathrm{C}$, and initial $\mathrm{pH}$ of 7.0).

340 The symbols and error bars represent the average and range, respectively, of duplicated formation tests. The dashed line indicates the equality line with a slope of 1.0.

The maximum formation potential (FP) of NDMA and NMOR by stabilized hypobromite or chloramine pre-treatment was also evaluated at an excessive chemical dose of $100 \mathrm{mg}-\mathrm{Cl}_{2} / \mathrm{L}$ and

344 an extended reaction period of $48 \mathrm{~h}$ (Table 3). The results revealed that chloramine treatment 345 resulted in a considerably high NDMA concentration of 207 and $89 \mathrm{ng} / \mathrm{L}$ in the UF-treated and 346 MBR-treated wastewaters, respectively. The high level of formation of NDMA, which occurred 347 as a result of the extended chloramination at a high chloramine dose, is consistent with previous 348 studies (Mitch and Sedlak, 2002; Farré et al., 2011a). High NMOR concentrations of 5-12 ng/L 
by chloramine was also observed for both treated wastewaters. In contrast, stabilized hypobromite resulted in very small concentrations of NDMA (1-8 ng/L) and NMOR (2.7-2.8 ng/L) for the two wastewaters. The low formation propensity of NDMA by hypobromite has been reported in literature (Luh and Mariñas, 2012), which explains the NDMA formation from DMA by bromine species (e.g., hypobromous acid, stabilized hypobromite ion, and tribromide ion) being over one magnitude lower than the one formed by monochloramine. Overall, the results indicate that predisinfection of treated wastewater prior to RO using stabilized hypobromite can form far less NDMA than that using chloramine.

Table 3 - Concentrations of $N$-nitrosodimethylamine (NDMA) and $N$-nitrosomorpholine (NMOR) at dose of $100 \mathrm{mg}-\mathrm{Cl}_{2} / \mathrm{L}$ and reaction time of $120 \mathrm{~h}$ (temperature of $25^{\circ} \mathrm{C}$ and initial $\mathrm{pH}$ of 7.0). The data represent the average and range of duplicated formation tests.

\begin{tabular}{lcccc}
\hline & \multicolumn{2}{c}{ UF (Plant A) } & \multicolumn{2}{c}{ MBR (Plant B) } \\
& Chloramine & $\begin{array}{c}\text { Stabilized } \\
\text { hypobromite }\end{array}$ & Chloramine & $\begin{array}{c}\text { Stabilized } \\
\text { hypobromite }\end{array}$ \\
\hline NDMA (ng/L) & $207.0 \pm 1.2$ & $7.5 \pm 0.5$ & $89.4 \pm 2.5$ & $1.4 \pm<0.1$ \\
NMOR (ng/L) & $12.2 \pm 0.1$ & $2.7 \pm 0.1$ & $4.6 \pm<0.1$ & $2.8 \pm<0.1$ \\
\hline
\end{tabular}

\subsubsection{NDMA formation potential}

361 Because NDMA formation can vary considerably depending on the NDMA precursors and their 362 concentrations in treated wastewaters, an investigation of the consistency of stabilized hypobromite in forming less NDMA than chloramine for various waters is important for the

364 viability of the new disinfectant. Thus, NDMA formation tests were conducted with the use of 365 high concentrations of three different NDMA precursors at high chemical doses and extended 366 periods of time (up to 120 h); Figure 5 shows these results. Throughout the tests, NDMA formation 367 by stabilized hypobromite was $2-5$ orders of magnitude lower than that by chloramine. For 368 example, after stabilized hypobromite treatment of DMA-containing solutions, the NDMA 
concentrations were only up to $4 \mathrm{ng} / \mathrm{L}(\mathrm{pH} 6)$ and $26 \mathrm{ng} / \mathrm{L}(\mathrm{pH} 8$ ), while the ones after chloramine treatment were $769 \mathrm{ng} / \mathrm{L}(\mathrm{pH} 6)$ and 1,544 ng/L (pH 8). Similar results were observed with the

371 TMA-containing solutions. Considerable variation in the NDMA concentration was observed with

372 DMBA (tertiary amine)-containing solutions; NDMA concentrations after stabilized hypobromite 373 and chloramine treatment at $\mathrm{pH} 8$ were 2 and $45,318 \mathrm{ng} / \mathrm{L}$, respectively. For both disinfectants, the 374 impact of solution $\mathrm{pH}$ on NDMA formation is the same; reactions at a high $\mathrm{pH}(\mathrm{i} . \mathrm{e} ., \mathrm{pH}=8$ ) yield 375 higher NDMA concentrations than those at a low $\mathrm{pH}$ (i.e., $\mathrm{pH}=6$ ). Because the NDMA 376 concentration after stabilized hypobromite treatment was consistently low regardless of $\mathrm{pH}$, it can 377 be concluded that the solution $\mathrm{pH}$ during stabilized hypobromite treatment is only a minor factor 378 for NDMA formation unlike in the case of chloramine treatment.

(i) $\mathrm{pH} 6$
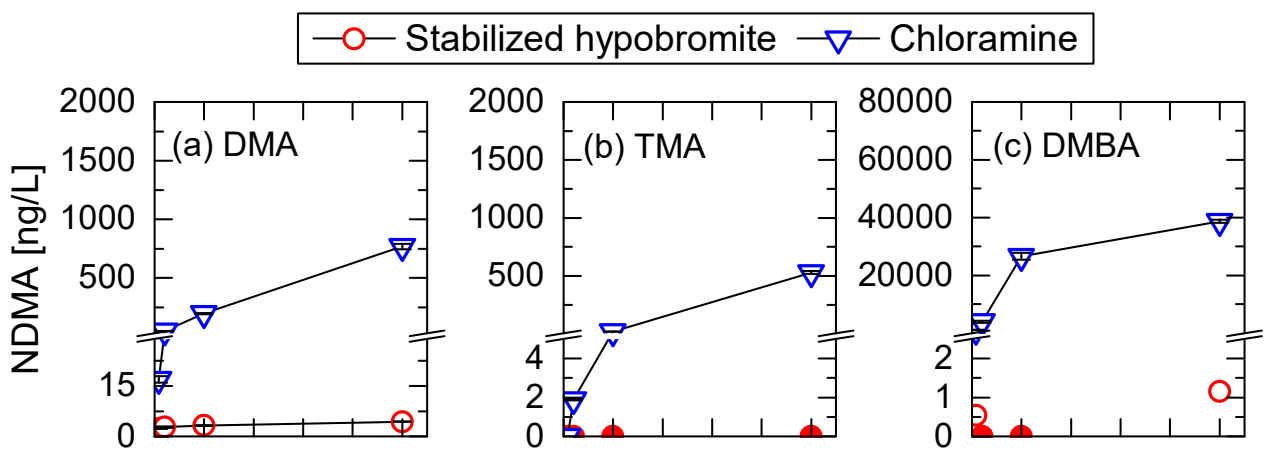

(ii) $\mathrm{pH} 8$
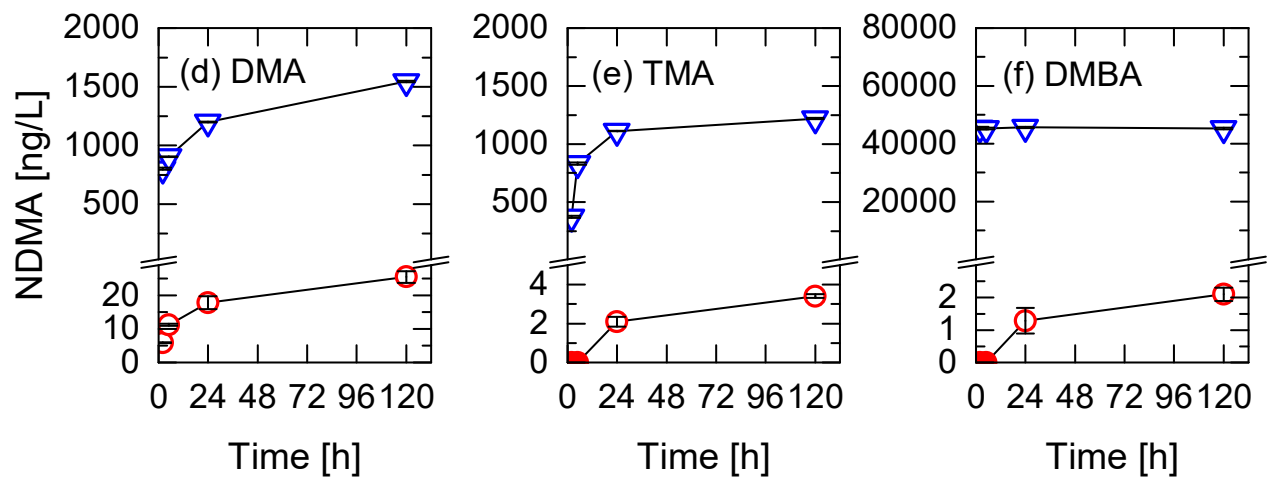

380 Figure $5-N$-nitrosodimethylamine (NDMA) concentrations in artificial wastewater containing $381100 \mu \mathrm{g} / \mathrm{L}$ of dimethylamine (DMA), trimethylamine (TMA), or dimethylbenzylamine (DMBA) at solution temperature of $25^{\circ} \mathrm{C}$ and solution $\mathrm{pH}$ values of (i) 6 and (ii) 8. Chloramine and stabilized hypobromite were dosed at $100 \mathrm{mg} / \mathrm{L}$. Symbols and error bars represent the average and range, 
respectively, of duplicated formation tests. Solid circle symbols represent concentrations below the detection limit.

Among the three NDMA precursors, NDMA formation by stabilized hypobromite treatment at $\mathrm{pH}$ 8 was higher with the secondary amine (DMA) than with tertiary amines (TMA and DMBA). This result is different from that of chloramine, which showed the highest yield with DMBA. For chloramine treatment, the maximum NDMA molar conversion rates (i.e., NDMA yields) achieved in this study were $<2 \%$ for DMA and TMA, and approximately $45 \%$ for DMBA (Figure 5), which are comparable with the yields reported in the literature (Mitch et al., 2003a; Selbes et al., 2013; Selbes et al., 2018). The variation among the three NDMA precursors can be attributed to the difference in charge. At $\mathrm{pH}$ values of 6 and 8, almost all DMA and TMA species are positively charged, whereas most DMBA species are uncharged (Table 1). Amine-based NDMA precursors are more reactive with chloramine in neutral (uncharged) forms (McCurry et al., 2017); thus, a change of NDMA precursors can play an important role in NDMA formation. In contrast, change of NDMA precursors is not an important factor for stabilized hypobromite treatment, although the causes of the higher NDMA formation potential with DMA over TMA and DMBA remained unclear in this study. Overall, the results demonstrated the versatility of stabilized hypobromite treatment for forming negligible amounts of NDMA during water recycling.

\section{Conclusions}

This study found that pre-disinfection using stabilized hypobromite affords more potent bactericidal effects than that using monochloramine for the same chemical dose, which indicates the high potential of stabilized hypobromite for mitigating biofouling during RO treatment. Among the 13 DBPs evaluated in the study, it was found that the formation of bromoform by stabilized hypobromite was higher than that by chloramine at a high dose of $10 \mathrm{mg} / \mathrm{L}$ and reaction time of 5 
h. This suggested a need for clarification of the chemical doses required to achieve a membrane

408

409

410 fouling mitigation effect similar to that of chloramine. In addition, NDMA formation by stabilized hypobromite treatment in two different types of treated wastewaters was found to negligible and considerably lower than that by chloramine treatment. Further, NDMA formation potential by stabilized hypobromite was $2-5$ orders of magnitude lower than that by chloramine. These results suggest the versatility of stabilized hypobromite treatment in terms of forming negligible amounts of NDMA during water recycling.

\section{References}

Bellona, C., Drewes, J.E., Oelker, G., Luna, J., Filteau, G., Amy, G., 2008. Comparing nanofiltration and reverse osmosis for drinking water augmentation. J. AWWA 100, 102116.

Boulos, L., Prévost, M., Barbeau, B., Coallier, J., Desjardins, R., 1999. LIVE/DEAD® BacLight ${ }^{\mathrm{TM}}$ : application of a new rapid staining method for direct enumeration of viable and total bacteria in drinking water. J. Microbiol. Methods 37, 77-86.

Chuang, Y.-H., Shabani, F., Munoz, J., Aflaki, R., Hammond, S.D., Mitch, W.A., 2019. Comparing industrial and domestic discharges as sources of $\mathrm{N}$-nitrosamines and their chloramine or ozone-reactive precursors. Environ. Sci.: Water Res. Technol. 5, 726-736.

Cran, M.J., Bigger, S.W., Gray, S.R., 2011. Degradation of polyamide reverse osmosis membranes in the presence of chloramine. Desalination 283, 58-63.

Cristiani, P., Perboni, G., 2014. Antifouling strategies and corrosion control in cooling circuits. Bioelectrochemistry 97, 120-126.

da Silva, M.K., Tessaro, I.C., Wada, K., 2006. Investigation of oxidative degradation of polyamide reverse osmosis membranes by monochloramine solutions. J. Membr. Sci. 282, 375-382.

Doederer, K., Farré, M.J., Pidou, M., Weinberg, H.S., Gernjak, W., 2014. Rejection of disinfection by-products by RO and NF membranes: Influence of solute properties and operational parameters. J. Membr. Sci. 467, 195-205.

Fang, J., Zhao, Q., Fan, C., Shang, C., Fu, Y., Zhang, X., 2017. Bromate formation from the oxidation of bromide in the UV/chlorine process with low pressure and medium pressure UV lamps. Chemosphere 183, 582-588. 
Farhat, N.M., Loubineaud, E., Prest, E.I.E.C., El-Chakhtoura, J., Salles, C., Bucs, S.S., Trampé, J., Van den Broek, W.B.P., Van Agtmaal, J.M.C., Van Loosdrecht, M.C.M., Kruithof, J.C., Vrouwenvelder, J.S., 2018. Application of monochloramine for wastewater reuse: Effect on biostability during transport and biofouling in RO membranes. J. Membr. Sci. 551, 243253.

Farré, M.J., Döderer, K., Hearn, L., Poussade, Y., Keller, J., Gernjak, W., 2011a. Understanding the operational parameters affecting NDMA formation at Advanced Water Treatment Plants. J. Hazard. Mater. 185, 1575-1581.

Farré, M.J., Keller, J., Holling, N., Poussade, Y., Gernjak, W., 2011b. Occurrence of Nnitrosodimethylamine precursors in wastewater treatment plant effluent and their fate during ultrafiltration-reverse osmosis membrane treatment. Water Sci. Technol. 63, 605612.

Fujioka, T., Khan, S.J., McDonald, J.A., Roux, A., Poussade, Y., Drewes, J.E., Nghiem, L.D., 2013a. $N$-nitrosamine rejection by nanofiltration and reverse osmosis membranes: The importance of membrane characteristics. Desalination 316, 67-75.

Fujioka, T., Khan, S.J., McDonald, J.A., Roux, A., Poussade, Y., Drewes, J.E., Nghiem, L.D., 2013b. $N$-nitrosamine rejection by reverse osmosis membranes: A full-scale study. Water Res. 47, 6141-6148.

Fujioka, T., Khan, S.J., Poussade, Y., Drewes, J.E., Nghiem, L.D., 2012. N-nitrosamine removal by reverse osmosis for indirect potable water reuse - A critical review based on observations from laboratory-, pilot- and full-scale studies. Sep. Purif. Technol. 98, 503515.

Fujioka, T., Oshima, N., Suzuki, R., Higgins, M., Price, W.E., Henderson, R.K., Nghiem, L.D., 2015. Effect of heat treatment on fouling resistance and the rejection of small and neutral solutes by reverse osmosis membranes. Water Sci. Technol. Water Supply 15, 510-516.

Furst, K.E., Pecson, B.M., Webber, B.D., Mitch, W.A., 2018. Distributed Chlorine Injection To Minimize NDMA Formation during Chloramination of Wastewater. Environ. Sci. Technol. Letters 5, 462-466.

Goh, P.S., Lau, W.J., Othman, M.H.D., Ismail, A.F., 2018. Membrane fouling in desalination and its mitigation strategies. Desalination 425, 130-155.

Gohil, J.M., Suresh, A.K., 2017. Chlorine attack on reverse osmosis membranes: Mechanisms and mitigation strategies. J. Membr. Sci. 541, 108-126.

Johns, C., Shellie, R.A., Potter, O.G., O’Reilly, J.W., Hutchinson, J.P., Guijt, R.M., Breadmore, M.C., Hilder, E.F., Dicinoski, G.W., Haddad, P.R., 2008. Identification of homemade inorganic explosives by ion chromatographic analysis of post-blast residues. J. Chromatogr. A $1182,205-214$. 
Kinani, S., Richard, B., Souissi, Y., Bouchonnet, S., 2012. Analysis of inorganic chloramines in water. TrAC Trends in Analytical Chemistry 33, 55-67.

Kodamatani, H., Roback, S.L., Plumlee, M.H., Ishida, K.P., Masunaga, H., Maruyama, N., Fujioka, T., 2018. An inline ion-exchange system in a chemiluminescence-based analyzer for direct analysis of N-nitrosamines in treated wastewater. J. Chromatogr. A 1553, 51-56.

Kodamatani, H., Yamazaki, S., Saito, K., Amponsaa-Karikari, A., Kishikawa, N., Kuroda, N., Tomiyasu, T., Komatsu, Y., 2009. Highly sensitive method for determination of Nnitrosamines using high-performance liquid chromatography with online UV irradiation and luminol chemiluminescence detection. J. Chromatogr. A 1216, 92-98.

Krasner, S.W., Mitch, W.A., McCurry, D.L., Hanigan, D., Westerhoff, P., 2013. Formation, precursors, control, and occurrence of nitrosamines in drinking water: A review. Water Res. 47, 4433-4450.

Le Roux, J., Gallard, H., Croué, J.-P., 2011. Chloramination of nitrogenous contaminants (pharmaceuticals and pesticides): NDMA and halogenated DBPs formation. Water Res. 45, 3164-3174.

Le Roux, J., Gallard, H., Croué, J.-P., 2012. Formation of NDMA and Halogenated DBPs by Chloramination of Tertiary Amines: The Influence of Bromide Ion. Environ. Sci. Technol. 46, 1581-1589.

Leddy, M.B., Hasan, N.A., Subramanian, P., Heberling, C., Cotruvo, J., Colwell, R.R., 2017. Characterization of Microbial Signatures From Advanced Treated Wastewater Biofilms. Journal - American Water Works Association 109, E503-E512.

Luh, J., Mariñas, B.J., 2012. Bromide Ion Effect on N-Nitrosodimethylamine Formation by Monochloramine. Environ. Sci. Technol. 46, 5085-5092.

McCurry, D.L., Ishida, K., Oelker, G., Mitch, W.A., 2017. Reverse Osmosis Shifts Chloramine Speciation Causing Re-Formation of NDMA during Potable Reuse of Wastewater. Environ. Sci. Technol. 51, 8589-8596.

Mitch, W.A., Gerecke, A.C., Sedlak, D.L., 2003a. A N-Nitrosodimethylamine (NDMA) precursor analysis for chlorination of water and wastewater. Water Res. 37, 3733-3741.

Mitch, W.A., Oelker, G.L., Hawley, E.L., Deeb, R.A., Sedlak, D.L., 2005. Minimization of NDMA formation during chlorine disinfection of municipal wastewater by application of pre-formed chloramines. Environ. Eng. Sci. 22, 882-890.

Mitch, W.A., Sedlak, D.L., 2002. Formation of N-Nitrosodimethylamine (NDMA) from dimethylamine during chlorination. Environ. Sci. Technol. 36, 588-595.

Mitch, W.A., Sharp, J.O., Trussell, R.R., Valentine, R.L., Alvarez-Cohen, L., Sedlak, D.L., 2003b. N-Nitrosodimethylamine (NDMA) as a drinking water contaminant: A review. Environ. Eng. Sci. 20, 389-404. 
Nikolaou, A.D., Lekkas, T.D., Golfinopoulos, S.K., Kostopoulou, M.N., 2002. Application of different analytical methods for determination of volatile chlorination by-products in drinking water. Talanta 56, 717-726.

NRMMC, EPHC, AHMC, 2008. Australian guidelines for water recycling: Managing health and environmental risks (Phase 2): Augmentation of drinking water supplies. Environment Protection and Heritage Council, National Health and Medical Research Council, Natural Resource Management Ministerial Council, Canberra.

Ohno, M., Manalo, C., Rossetto, L., Okuda, T., Nakai, S., Nishijima, W., 2016. Effect of coexisting metal ions on the degradation of polyamide reverse osmosis membrane by hypochlorite treatment. Desalination 381, 126-134.

Park, J.W., Kim, H.-C., Meyer, A.S., Kim, S., Maeng, S.K., 2016. Influences of NOM composition and bacteriological characteristics on biological stability in a full-scale drinking water treatment plant. Chemosphere 160, 189-198.

Plumlee, M.H., López-Mesas, M., Heidlberger, A., Ishida, K.P., Reinhard, M., 2008. Nnitrosodimethylamine (NDMA) removal by reverse osmosis and UV treatment and analysis via LC-MS/MS. Water Res. 42, 347-355.

Schreiber, I.M., Mitch, W.A., 2005. Influence of the order of reagent addition on NDMA formation during chloramination. Environ. Sci. Technol. 39, 3811-3818.

Sedlak, D.L., Deeb, R.A., Hawley, E.L., Mitch, W.A., Durbin, T.D., Mowbray, S., Carr, S., 2005. Sources and fate of Nitrosodimethylamine and its precursors in municipal wastewater treatment plants. Water Environment Research 77, 32-39.

Selbes, M., Beita-Sandí, W., Kim, D., Karanfil, T., 2018. The role of chloramine species in NDMA formation. Water Res. 140, 100-109.

Selbes, M., Kim, D., Ates, N., Karanfil, T., 2013. The roles of tertiary amine structure, background organic matter and chloramine species on NDMA formation. Water Res. 47, 945-953.

Sgroi, M., Vagliasindi, F.G.A., Snyder, S.A., Roccaro, P., 2018. N-Nitrosodimethylamine (NDMA) and its precursors in water and wastewater: A review on formation and removal. Chemosphere 191, 685-703.

Sharma, V.K., Zboril, R., McDonald, T.J., 2014. Formation and toxicity of brominated disinfection byproducts during chlorination and chloramination of water: A review. Journal of Environmental Science and Health, Part B 49, 212-228.

Shen, R., Andrews, S.A., 2011. Demonstration of 20 pharmaceuticals and personal care products (PPCPs) as nitrosamine precursors during chloramine disinfection. Water Res. 45, 944-952.

Snyder, S.A., Vanderford, B.J., Rexing, D.J., 2005. Trace Analysis of Bromate, Chlorate, Iodate, and Perchlorate in Natural and Bottled Waters. Environ. Sci. Technol. 39, 4586-4593. 
Spahr, S., Cirpka, O.A., von Gunten, U., Hofstetter, T.B., 2017. Formation of NNitrosodimethylamine during Chloramination of Secondary and Tertiary Amines: Role of Molecular Oxygen and Radical Intermediates. Environ. Sci. Technol. 51, 280-290.

Stolov, M., Freger, V., 2019. Degradation of Polyamide Membranes Exposed to Chlorine: An Impedance Spectroscopy Study. Environ. Sci. Technol. 53, 2618-2625.

Tang, C.Y., Yang, Z., Guo, H., Wen, J.J., Nghiem, L.D., Cornelissen, E., 2018. Potable Water Reuse through Advanced Membrane Technology. Environ. Sci. Technol. 52, 10215-10223.

Warsinger, D.M., Chakraborty, S., Tow, E.W., Plumlee, M.H., Bellona, C., Loutatidou, S., Karimi, L., Mikelonis, A.M., Achilli, A., Ghassemi, A., Padhye, L.P., Snyder, S.A., Curcio, S., Vecitis, C.D., Arafat, H.A., Lienhard, J.H., 2018. A review of polymeric membranes and processes for potable water reuse. Prog. Polym. Sci. 81, 209-237.

West, D.M., Wu, Q., Donovan, A., Shi, H., Ma, Y., Jiang, H., Wang, J., 2016. N-nitrosamine formation by monochloramine, free chlorine, and peracetic acid disinfection with presence of amine precursors in drinking water system. Chemosphere 153, 521-527.

WHO, 2011. Guidelines for drinking-water quality 4th edition. World Health Organization, Geneva.

WHO, 2017. Potable reuse: guidance for producing safe drinking-water. World Health Organization, Geneva.

Xie, Y., 2001. Analyzing Haloacetic Acids Using Gas Chromatography/Mass Spectrometry. Water Res. 35, 1599-1602.

Yang, J., Li, J., Dong, W., Ma, J., Yang, Y., Li, J., Yang, Z., Zhang, X., Gu, J., Xie, W., Cang, Y., 2017. Enhancement of bromate formation by $\mathrm{pH}$ depression during ozonation of bromidecontaining water in the presence of hydroxylamine. Water Res. 109, 135-143.

Zhou, W., Chen, C., Lou, L., Yang, Zhu, L., 2014. Formation potential of nine nitrosamines from corresponding secondary amines by chloramination. Chemosphere 95, 81-87. 